\title{
Identifying the Liquidity Effects of Monetary Policy Shocks for a Small Open Economy: Turkey
}

\author{
M. Hakan Berument • Selahattin Togay • \\ Afsin Sahin
}

Published online: 14 January 2010

(C) Springer Science+Business Media, LLC 2010

\begin{abstract}
This paper proposes a new liquidity measure for a small open economy. The new measure includes the net liquidity provided to the system by a central bank after accounting for the central bank's involvement in the foreign exchange market. Empirical evidence gathered from Turkey suggests that a positive innovation in liquidity increases output temporarily and that its effect on prices, exchange rate and money are permanently higher.
\end{abstract}

Keywords Liquidity effect - Open economy version of NBR .

Small and open economies $\cdot$ VAR models

JEL Classification E50 $\cdot \mathrm{E} 52 \cdot \mathrm{E} 43$

\section{Introduction}

A considerable number of studies examine the behavior of business cycles that experience exogenous monetary policy shocks. Most of these studies analyze

All the views expressed in this paper belong to the authors and do not necessarily represent the views of the Ministry of Agriculture and Rural Affairs.

M. H. Berument $(\bowtie)$

Department of Economics, Bilkent University, 06800 Ankara, Turkey

e-mail: berument@bilkent.edu.tr

URL: http://www.bilkent.edu.tr/ berument

S. Togay

Department of Economics, Gazi University, 06500 Ankara, Turkey

e-mail: stogay@gazi.edu.tr

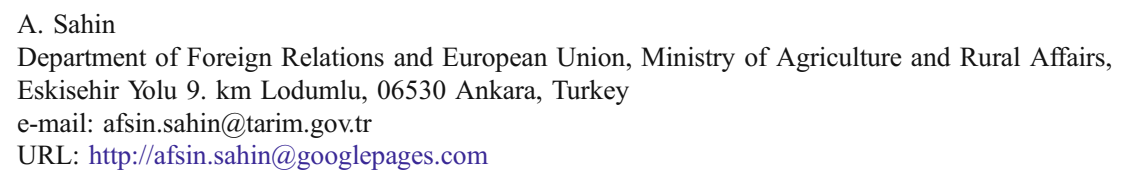


developed countries, particularly the United States (see Christiano et al. 1999 and the references cited therein). Using similar methodologies for developing countries, however, may not be appropriate. Central banks in developing countries may have concerns that extend beyond those in the studies and, even if they cannot use them simultaneously, may use additional tools that affect their economic performances. Foreign exchange (FX) rates and the foreign exchange reserves of a central bank are two of the variables that central banks of developing countries concern themselves with. Foreign exchange rates directly affect inflation through higher foreign demand for domestic goods or higher input costs. ${ }^{1}$ Moreover, depending on the exchange rate regime, expansionary monetary policy shocks may affect economic performance differently. Last, the foreign exchange rate regime itself could be considered part of a country's monetary policy.

In the literature, using the funding of central banks through open market operations to the markets - non-borrowed reserves (NBR) - as an indicator of monetary policy is common. Again, most of the studies have been done on the US economy (see for example Rudebush 1998; Christiano and Eichenbaum 1992b; Christiano 1995; Eichenbaum 1992; Bernanke and Mihov 1998; Bernanke and Blinder 1992; Strongin 1995; Pagan and Robertson 1995 and Thornton 2001). Christiano and Eichenbaum (1992b) and Pagan and Robinson (1995) find evidence that positive shocks to NBR decrease short-term interest rates. Strongin (1995) proposes to use the non-borrowed reserves' growth to identify monetary policy disturbances. However, a limited number of studies use NBR as a stance of monetary policy for developed countries other than the US; for Japan, see for example Kasa and Popper (1997) and Shioji (2000).

Vector autoregression (VAR) models are the most common econometric method used to assess the effect of monetary policy changes on economic performance. Innovations to money aggregates were the variables used to measure monetary policy initially (see Sims 1972; Stock and Watson 1989 and Rotemberg et al. 1995). Christiano and Eichenbaum (1992a) claim that innovations to broad money aggregates reflect shocks to money demand rather than money supply. Friedman and Kuttner (1992) also argue that this relationship is not stable. The second variable considered was innovations to the interest rate (see Bernanke and Blinder 1992 and Sims 1992). This variable is often associated with a set of empirical puzzles, such as the price puzzle (positive interest rate shocks are associated with higher rather than lower prices) and the exchange rate puzzle (positive interest rate shocks are associated with depreciating rather than appreciating currency).

The spread between short-term interest rates and other financial variables is also considered as a measure of monetary policy. In the literature, several studies use short-term/long-term interest rate spreads, and consider the term structure of interest rates as an indicator of monetary policy stance (see also Mankiw and Miron 1986 for the predictive power of this spread illustration). More specifically, Bernanke (1990) calculates the spread as the difference between commercial paper and a Treasury bill, Laurent (1988) considers the spread between the 20-year Treasury bill's constant maturity and the federal funds rate, and McCallum (2005) considers the difference

\footnotetext{
${ }^{1}$ Kamin and Rogers (2000) provide an excellent survey on the possible effects of foreign exchange movements on economic performance.
} 
between yields on one-period and two-period (long rate) bonds in general. Berument (2007) examines the short-term interest rate and the depreciation rate spread as a measure of monetary policy for Turkey.

The fourth variable, non-borrowed reserves, is the remainder of total reserves when borrowed reserves are subtracted, and is used in identifying monetary policy. The non-borrowed reserves variable is a narrower monetary aggregate, and compared to the broader monetary aggregates, has some advantages in measuring the stance of monetary policy and in identifying monetary policy disturbances. When broader monetary aggregates are used to measure exogenous policy disturbances, some traditional and common technical sovereignty problems arise. First, central banks cannot control the broader monetary aggregates such as M1 and M2. Second, the broader monetary aggregates are the measures of liquidity and are affected by the state of the economy as well as by the country's monetary policy. Non-borrowed reserves is a more controllable variable when the standard definition given by the Federal Reserve System is considered. (We elaborate on the calculation equivalent of NBR for developing countries in the following sections.)

Buying (or selling) foreign exchanges injects (ejects) liquidity into (or from) the markets; any study that assesses the monetary policy stance for a small open economy needs to account for the liquidity provided by the foreign exchange transactions of central banks. The contribution of this paper to the literature is to generate a monetary policy measure that accounts for foreign exchange transactions. To the best of our knowledge, there is no other study that develops a liquidity measure that accounts for the foreign exchange transactions for any developing country. Our variable, as we will discuss in the next section, will assess how the liquidity provided to markets as determined both by open-market operations and foreign exchange markets where the latter is not explicitly accounted for in the conventional non-borrowed reserves definition affects the economic performance.

We define and assess the role of the new liquidity measure for Turkey. There are various reasons for gathering data from Turkey. First of all, the Central Bank of the Republic of Turkey (CBRT) has always been actively involved in the foreign exchange market and the money markets. ${ }^{2}$ This is not the case with all developing countries; some have fixed exchange rates or an orthodox currency board regime where, when central banks buy foreign exchange, they passively generate liquidity in domestic currency. Second, the average annual consumer price inflation rate for the sample we consider is $51.2 \%$, and Turkey is the only country that has had high inflation for more than three decades without running hyper inflation. Higher levels of inflation, and financial variables such as interest rates and exchange rates, make the relationship between monetary policy variables and macroeconomic variables more visible, therefore detecting these relationships will be easier. In other words, the Type II Error (the probability of not rejecting the null hypothesis when it is false) is lower. Third, Turkey has had well-developed, well-functioning and liberal financial markets; prices determined in these markets are therefore representative

\footnotetext{
${ }^{2}$ See Berument (2007) for the CBRT's monetary policy practice. Turkey did not fix its exchange rate, and the only exception for Turkey is that it had a crawling peg exchange rate regime for the period from January 2000 to February 2001. As this is a brief amount of time, we did not explicitly address it. For the remaining period, the CBRT was either an active participant on the foreign exchange market or it made its preferences known to the public such that it could enter the market when it desired.
} 
of the relative scarcity of financial assets rather than as the act of a few manipulators. These three conditions make Turkey a unique (developing) small open economy for which to assess the role of financial variables on economic variables.

The outline of the paper is as follows: The next section (Section II) elaborates on the liquidity measure that the paper uses. Section III introduces the methodology. Section IV discusses the development of Turkey's monetary policy by using the liquidity introduced in Section III. Section V discusses the effects of a loose monetary policy. The last section summarizes and concludes.

\section{A liquidity measure for small open economies}

Innovations in non-borrowed reserves is one of the monetary policy measures followed by US economic policy participants. NBR is calculated as the difference between a banking system's total reserves (TR) and its borrowed reserves, and the ratio of NBR to TR is taken as a liquidity measure. However, innovations in this ratio may not be appropriate as monetary policy changes for a small open economy that has an incentive to intervene in the foreign exchange market to stabilize its foreign exchange volatilities as well as to use the foreign exchange market for controlling liquidity in the markets. There might be various reasons for these decisions. For example, buying foreign exchange in local currency, which increases liquidity in the markets, decreases the NBRto-TR ratio; buying foreign exchange does not change NBR but increases TR. An additional problem arises if the central bank desires to sterilize excess liquidity that is provided by buying foreign exchange. In the next stage, as the central bank sells treasury securities for decreasing the pressure on the markets (open-market operations), NBR further decreases. Since the latter option does decrease NBR under incomplete sterilization (when purchases of treasuries do not match with foreign exchange buys) the NBR-to-TR ratio further decreases rather than increases. Thus, increase in liquidity suggests a decrease in the NBR-to-TR ratio rather than an increase: this is a problem. We therefore offer a new appropriate measure of monetary policy that incorporates the foreign exchange market operations of central banks.

The developments in the Turkish economy also suggest that the NBR-to-TR ratio is not an appropriate measure of monetary policy stance. During the period of 1990 to 1997 , the CBRT openly encouraged the banking sector to undertake involved transactions with each other rather than receive liquidity from the CBRT; the borrowed reserves then diminished continuously and NBR increased. In this period, the CBRT also continued to accumulate its foreign exchange reserves; this let liquidity in the system diminish. As we will discuss below and as noted in Berument (2007), this period was an era of tight monetary policy (except for few instances) and, excluding the role of the foreign exchange markets, lets us draw misleading conclusions. Moreover, in the post-February 2000 era, the Borrowed Reserve-to-TR ratio has diminished to a level we can disregard and for this reason, as seen in Fig. 1, the NBR-to-TR ratio converges to a constant number and its limit is 1 . This situation lets the NBR-to-TR ratio give an unhealthy signal concerning the development of market liquidity in different economic conjectures. Therefore, it is reasonable to expect that the explanatory power of the NBR-to-TR ratio to be low for any macroeconomic variable that we consider. 


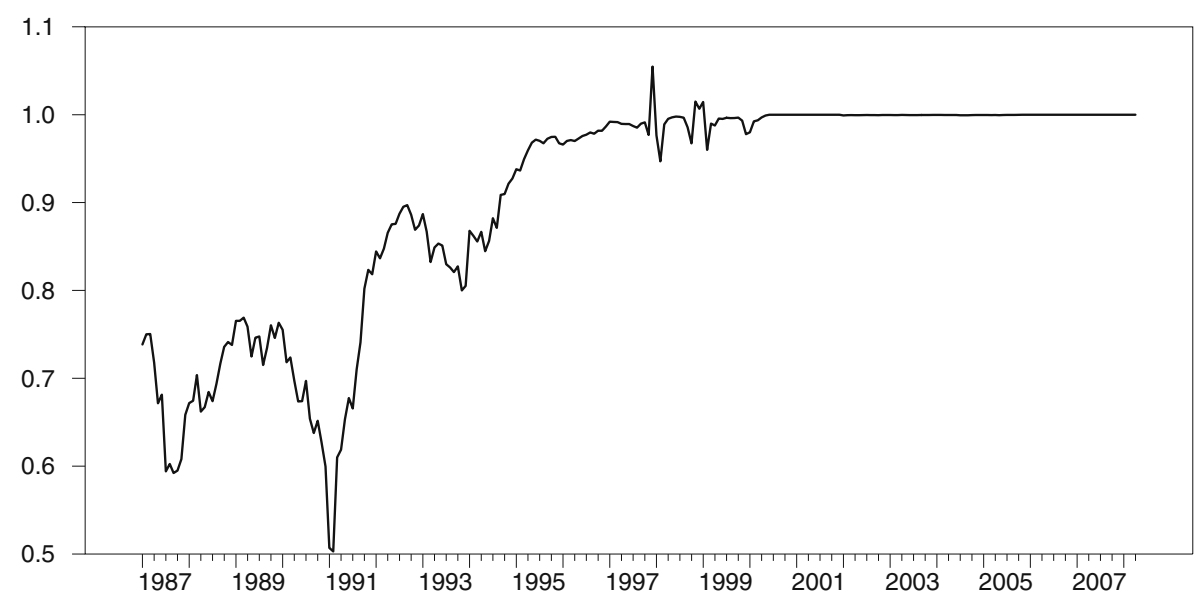

Fig. 1 Non-borrowed reserves in Turkey (1986:01-2008:04)

In this study, we propose a new liquidity measure calculated from the CBRT's analytical balance sheet. To this end, we first define the central bank's Foreign Currency Operations (CT) item. According to this, CT is the difference between the Central Bank Money (CBM) and the Cash Operations (CO). In addition, to reach the liquidity provided by the CBRT in the market, we subtract the Open Market Operations (OM) from the Foreign Currency Operations (CT), then we divide this difference by Total Reserves (TR) to obtain the liquidity measure. To obtain the TR size, we classify the entries on the CBRT balance sheet into three groups: Autonomous factors $(\mathrm{A})$, monetary policy operations $(\mathrm{M}+\mathrm{B})$ and reserves of banks. To be specific, by following Bindsell (2004), where the total reserve size is calculated as $\mathrm{TR}=\mathrm{OM}+\mathrm{B}+\mathrm{A}$ ( $\mathrm{M}$ being open-market operations, $\mathrm{B}$ being borrowed reserve and A being autonomous factors), it follows that $\mathrm{NBR}=\mathrm{OM}+\mathrm{A}$. The net autonomous factors in Turkey are positive, therefore we consider A as a positive variable in the equation. Thus, our liquidity measure $L$ can be defined as:

$$
L=\frac{C B M-C O-O M}{M+B+A}
$$

(The sources, definitions and calculations of all the data are provided in Table 2).

The plot of the new liquidity measure is provided in Fig. 2. We could deflate the nominator with an aggregate that also includes the total foreign exchange reserves of the CBRT. Turkey had signed four standby agreements with the International Monetary Fund (IMF) for the period that we consider. These agreements involved various installments in foreign currency (SDR). Moreover, Turkey had an ambitious privatization program where the payments were made mostly in US dollars. Once these two types of payments were made, foreign exchange reserves of the CBRT changed. Since determining when these payments were made is not easy to trace, we did not include a measure of foreign reserves in the denominator. Moreover, including foreign exchange reserve changes without accounting for the dates of these events may give a signal of tight monetary policy even if the stance of the monetary policy is intact. Thus, we did not incorporate the total foreign exchange reserves in the denominator. 


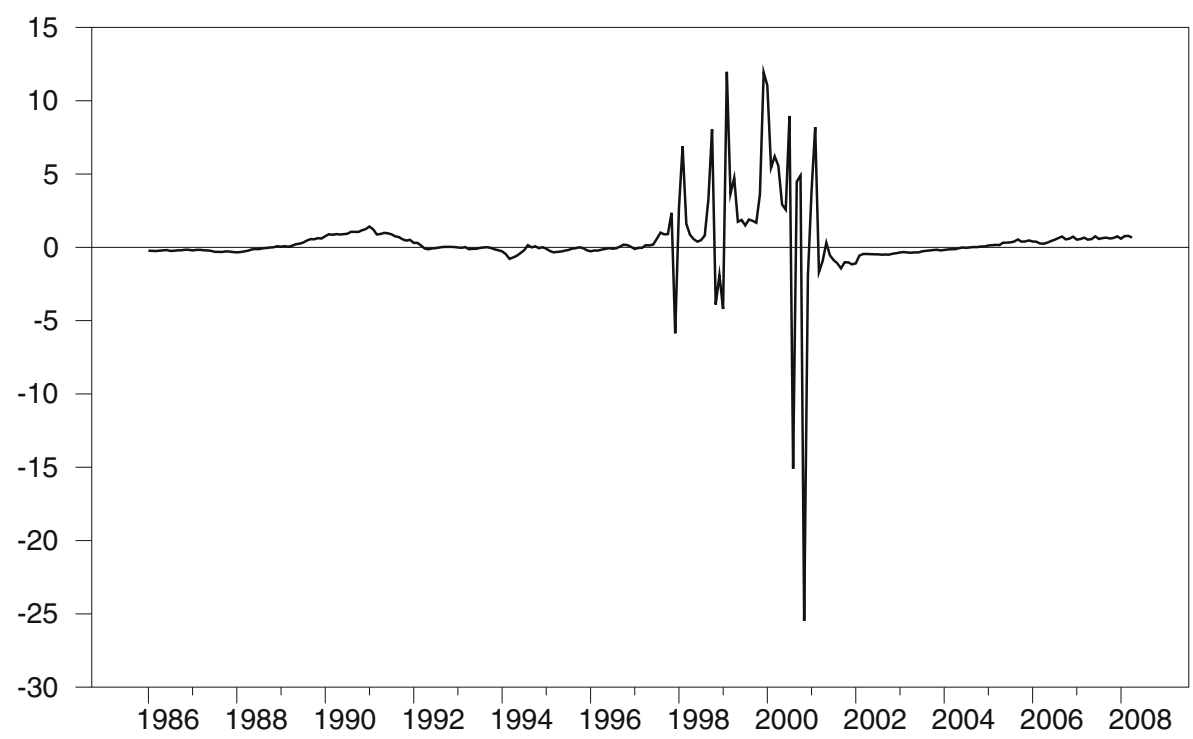

Fig. 2 (Currency transactions - open-market operations)/R

\section{Methodology}

Identifying the effects of monetary policy on economic performance is not a simple task because the actions of a central bank are determined by the state of the economy as well as by the bank's monetary policy. In order to capture the effect of the central bank's monetary setting, identifying the variables that the central bank is not reacting to is important. By following Christiano et al. (1999) and the references cited therein, we specify a VAR model to capture that part of the monetary policy. Here, we consider the liquidity-to-TR ratio as the central bank's policy variable.

The variables that we include to the VAR specification are income $(y)$, prices $(p)$, liquidity/total reserves ratio $(L)$, exchange rate (exchange) as defined by the Turkish lira value of the US dollar, the interbank interest rate (interbank) and money $(m)$. We use industrial production as a measure of income and the wholesale price index for prices. There are two reasons for this decision: $i$. In the majority of the sample, the CBRT used the wholesale price index as an inflation measure. ii. Industrial production is more likely to move with the wholesale price index than the consumer price index. Money is M1. We gathered all the data from the CBRT's electronic data delivery system covering the monthly period from 1987:01 to 2008:04.

In order to identify monetary policy shocks, the order of the variables in the VAR setting are income $\left(y_{t}\right)$, prices $\left(p_{t}\right)$, liquidity/total reserves ratio $\left(L_{t}\right)$, exchange rate (exchange $)_{t}$, the interbank interest rate (interbank) and money $\left(m_{t}\right)$. All the variables enter to the specification in their logarithmic levels except for $L$ and the interbank rate. ${ }^{3}$ However, similar to Cook (1999), Kim (2001), Kim (2003), Jang and Ogaki

\footnotetext{
${ }^{3}$ Faust et al. (2004), Hanson (2006), Normandin and Phaneuf (2004), Uhlig (2005), Silva (2008), Bernanke and Blinder (1992), Christiano et al. (1999) and Croushore and Evans (2006) use NBR in its logarithmic form. Since NBR may take negative values, we enter liquidity measure as its ratio to TR, rather than in its logarithmic form.
} 
(2004) and Scholl and Uhlig (2008), liquidity enters as a ratio to total reserves. This ordering scheme is consistent with our basic identification assumption that monetary policy does not have any contemporaneous effect on income and prices but income and prices do affect the central bank's policy stance. This ordering incorporates the extreme information assumption: that policy makers know the current levels of income and prices. Quarterly data may be used, but when we do this we also assume that monetary policy shocks do not affect income and prices in the current period; this may not be true. Using the assumption that monetary policy does not affect income and prices is more reasonable for monthly data than for quarterly data. Moreover, it is also reasonable to assume that the central bank sets its monetary policy monthly rather than quarterly. And as the data span available is so narrow for Turkey, this is another reason for using monthly data instead of quarterly data for our analyses. Further, Geweke and Runkle (1995), Bernanke and Mihov (1998) and Christiano et al. (1999) also suggest that the inferences gathered from quarterly data are in line with monthly data.

Ordering $L$ before the interbank interest rate suggests that the interbank interest rate responds to $L$ contemporaneously. This is a valid assumption if we take $L$ as a measure of monetary policy. Later in the paper, we will also consider that the interbank rate (or the spread between the interbank rate and the exchange rate depreciation) may be used as a policy tool for central banks. Thus, if one takes the interbank rate as an indicator of monetary policy, the interbank rate should precede $L$ (see Strongin 1995 for discussion). Ordering exchange rate before spread goes along with the practices of the central bank before 2001 (see Berument 2007 for this discussion). Since 2001, and particularly since 2003, Turkish exchange rate movements are mostly driven by world (excess) liquidity than by the actions of the CBRT. The CBRT often argued that due to the inflation target regime that they had, they could not set up the monetary policy to affect the exchange rate, and setting up the exchange rate during the appreciation period that Turkey experienced would have threatened their target inflation (see CBRT 2007 for details.)

The lag order of the VAR specification is 2, as determined both by the Schwartz and Hannan-Quinn information criteria. When the VAR model is estimated to account for seasonality, twelve monthly dummies are included; in order to account for the April 1994 financial crisis, we include dummies for April and May of 1994. In order to account for the November 2000 and February 2001 crises, we include two additional dummy variables.

\section{Developments of monetary policy}

In this section, before we assess the effects of monetary policy shocks on economic performance, we will discuss the stance of monetary policy by considering the specification that we use in this paper, and elaborate on it by considering the developments of the perceived monetary policy stance. Figure 3 plots the accumulated liquidity innovations; downward movement in the figure represents tight monetary policy and upward movement represents loose monetary policy. Thus, we will be able to elaborate on the stance of monetary policy by looking at the graph as suggested by our specification. 


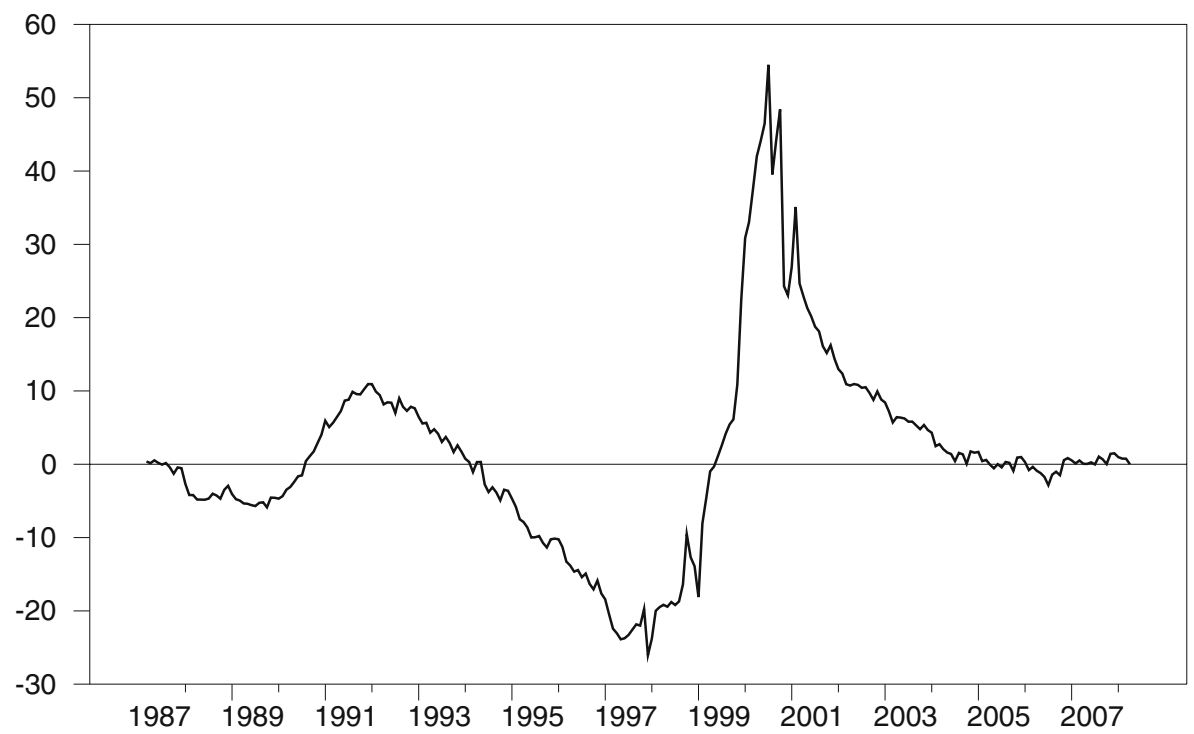

Fig. 3 The implied stance of monetary policy: accumulated summation of $L$ innovations

Overall, the implied monetary policy from Fig. 3 matches with the announced (or perceived) monetary policy stance. For the period from 1987:03 to 1988:06, monetary policy seems to be tight; this is when Turkey adopted its first monetary program. The program was not announced to the public, and its main concept was based upon a monetarist framework: the CBRT had tried to control the M2 monetary aggregate (Kumcu et al. 1987). The program was discontinued 1 year later due to political pressure on the government regarding election timing. Loose monetary policy can be seen for the following 6 months, from June 1988 to December 1988 (A referendum regarding rescheduling local election timing was held on September 25, 1988.) The loose monetary policy ended with increasing pressure on the economic system that led to dollarization of the system, which ultimately led, in February 1989, to Turkey adopting a set of codes that is associated with tight monetary policy.

Tight monetary policy continued until August 1989. Capital flow controls had been abandoned and the Turkish lira was made convertible with major world currencies in August 1989 with the adaptation of Code 32. This encouraged foreign capital inflow for portfolio investments. The effect of capital inflows on CBRT reserves mimicked itself with higher money supply. The effect of this as loose monetary policy can be detected from Fig. 3 for the period from 1989:10 to 1992:01.

In January 1992, after the pressure of the First Gulf War eased for Turkey, the CBRT announced its new monetary program. Although CBRT's monetary targets were not achieved at all later in that year, this program is considered the beginning of Turkey's tight monetary policy (see Fig. 3). Five years later, the Asian crisis that began in July 1997 put pressure on the Turkish government to loosen its monetary policy. Further, political turmoil that led to Turkey's prime minister resigning in June 1997 and a new prime minister being "implemented" increased pressure on the 
government to adopt populist policies. These factors contributed to loose monetary policy for the period from 1997:07 to 2000:07.

Turkey adopted an exchange-based stabilization program in December 1999 to start January 2000. Due to its nature, this program was expansionary in its early stages (see Agénor and Montiel 1999, for details). Parallel to this, a loose policy stance can be observed from Fig. 3. The highest liquidity is observed in July 2000. A higher current account deficit put pressure on the CBRT's reserves and the lower liquidity associated with it mimicked itself with tight policy in the later stages of the exchange-based stabilization program. When we look through the period from 2000:07 to 2006:07, we observe that monetary policy was tight. This stance of tightness was evident in that the CBRT had had implicit inflation targeting and realized inflation rates that were lower than the announced targeted levels for the years 2004 and 2005.

A new CBRT president was appointed in April 2006. Financial markets were turbulent in May 2006 and the turbulence continued until June. During this period, it seems that the CBRT, parallel to the signed IMF agreement, had a tight monetary policy. ${ }^{4}$ Figure 3 shows higher inflation after July 2006, which suggests that the stance of tight monetary policy had eased. Realized inflation rates were higher than the publicly announced target rates for 2006, 2007 and 2008.

\section{Empirical evidence}

In this section, we will assess the effects of change in monetary policy by using the specification introduced in Section III. It is expected that expansionary monetary policy is associated with initially lower interest rates, a higher exchange rate (depreciation) and higher monetary aggregates. Interest rates may later increase due to inflationary and exchange rate pressures. Moreover, with loose monetary policy, prices rise and there should be no decrease in output level. It is also plausible that loose monetary policy is associated with higher output levels.

The impulse responses of the six macroeconomic variables when a one-standarddeviation shock is given to each $L$ and interbank interest rate for 24 periods are reported in Fig. 4. The first column of Fig. 4 reports the effect of a one-standarddeviation shock to $L$ for output, prices, exchange rate, $L$, interbank and money. The middle line shows the point estimates, the other two lines are plus and minus onestandard-error confidence intervals. ${ }^{5}$ Taking a one-standard-error confidence band is in line with Sims and Zha (1999) and Shioji (2000). They claim that taking the confidence band higher than one standard error is too restrictive for testing corresponding hypotheses.

Evidence suggests that a one-standard-deviation shock to $L$ increased output for five periods and this increase is statistically significant for the first two periods. The hump shape of the output's response is parallel to empirical evidence from the US

\footnotetext{
$\overline{{ }^{4} \text { A former CBRT vice president }}$ who left his position in March 2006 (the CBRT has four vice-president positions) acknowledged in his column in a daily newspaper in June 2006 that the monetary policy was still tight (see Ozatay 2006).

${ }^{5}$ In order to calculate the confidence bands we used the Monte Carlo method with 1000 iterations by using the MALCOLM procedure for RATS (see Mosconi 1998).
} 


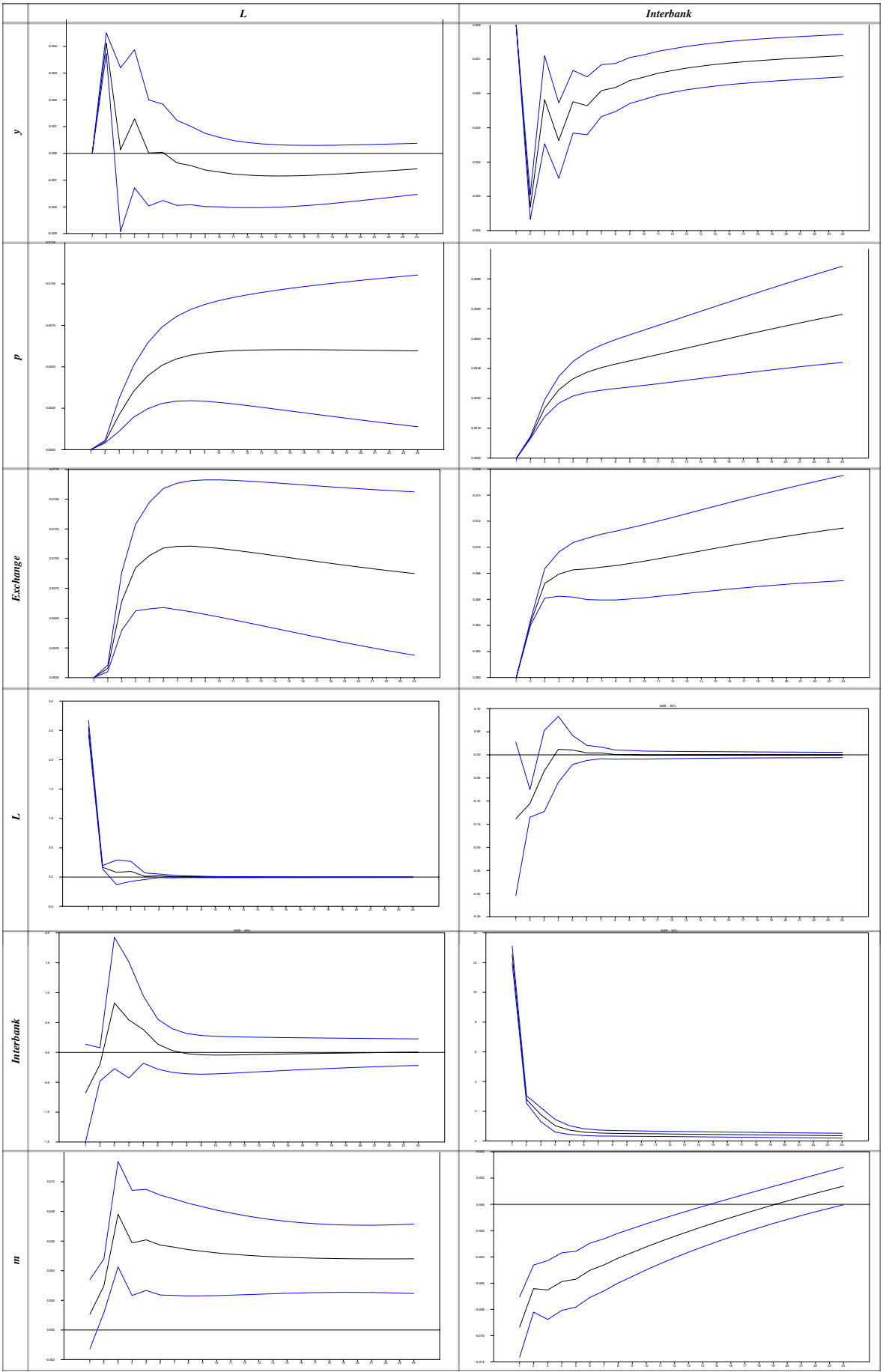

Fig. 4 The effect of monetary policy shocks on economic performance with interest rates 
(Christiano et al. 1999) and from Turkey (Berument 2007). Prices also tended to accelerate. Prices stabilized after about 8 months and this effect is statistically significant for the time horizon that we consider. A positive shock to $L$ increased the exchange rate for six periods, and even when the exchange rate decreased from its peak, it remained higher for the period that we consider; this effect is persistent and statistically significant. A shock to $L$ is not persistent. A higher $L$ is associated with lower interest rates initially, but even with an increase in interest rates after the second period this effect is not statistically significant. The last row reports the impulses for money. Money aggregates increase and remain high for the 24 periods that we consider. The effect is statistically significant for the whole period but contemporaneously. Thus, lower interest rates associated with a positive innovation in $L$ suggest that we do not have the liquidity puzzle (see Carpenter and Demiralp 2008, and literature cited therein for the liquidity puzzle). These empirical findings on six macroeconomic variables are in line with economic theory and parallel to existing empirical studies such as Strongin (1995), Eichenbaum and Evans (1995) and Christiano et al. (1999).

Bernanke and Blinder (1992) and Sims (1992) suggest using innovations in shortterm interest rates to capture the stance of monetary policy. The second column of Fig. 4 reports the impulse responses when a one-standard-deviation shock is given to the interbank interest rate. When we order the variables in the VAR, interbank rate is ordered before the liquidity measure. This re-ordering implies that interest rate (as a monetary policy variable here) affects $L$ but is not affected by $L$ contemporaneously. This goes with the spirit of identifying monetary policy as we discussed in Section III. A positive innovation in interbank rate decreases output, decreases $L$ and decreases money (at least initially). These are parallel to economic theory. However, positive innovation in interbank interest rate increases prices and exchange rates. These are two well-known phenomena and are named price and exchange puzzles in the literature (see Kim and Roubini 2000 for discussion of this issue.) Thus, we may take the existence of these two puzzles as not innovations in interest rates, but innovations in $L$ can be taken as an indicator of monetary policy changes.

In order to more comprehensively assess the theoretical consistency of the dynamic interactions among the variables in our VAR set up, we also estimate how the innovations of six variables affect the variables themselves. In order to save space, these figures and the other figures that are discussed but not reported here is available from http://www.bilkent.edu.tr/ berument/liquidity_wp.pdf. ( The effect of positive exchange rate innovation decreases output and increases prices and interest rate. These are parallel to earlier empirical evidence. Higher exchange rate lowers output due to higher input prices and wage demands (see for example Kamin and Rogers 2000; Berument and Pasaogullari 2003 and Sahin 2009). A higher price is due to exchange-rate-pass-through and a higher interest rate due to uncovered interest rate parity conditions.

Empirical evidence on other variables is also in line with the workings of the Turkish economy. The Turkish Central Bank has a low level of independence from the government (see Cukierman 1992 and Berument and Neyapti 1999). Moreover, the CBRT often pursues accommodative monetary policies (Berument and Tasci 2004). In that spirit, our estimates are in line with expectations. In order to see how the various types of shocks affect $L$, the evidence suggests that a positive shock to 
prices initially decreases liquidity (not significantly and it later increases $L$ ). Higher $L$ suggests existence of the accommodative policies of the CBRT; moreover, a shock to money increases liquidity provided by the central bank to accommodate the markets. The initial response of $L$ to interbank rate shock is negative, which is parallel to Croushore and Evans (2006, Fig. 2). The increase in interest rate is associated with lower liquidity. However, it seems that liquidity does not respond to exchange rate and output. These are all parallel with earlier literature on Turkey. Berument and Tasci (2004) argue that the CBRT does not respond to exchange rate and output movements in a statistically significant fashion but does monitor the foreign exchange reserves. Higher foreign exchange rates are associated with higher demand in the foreign exchange market (that mimics itself with higher overnight interest rates) because the CBRT decreases the liquidity to deplete FX demands from its inflated levels under excess FX demands. (See a discussion on this issue from a former vice president of the CBRT, Şükrü Binay, in Aydogdu and Yonezer 2007).

Berument (2007) uses the spread between the interbank rate and monthly depreciation rate of the Turkish lira as an indicator of the stance of monetary policy for Turkey. He considers the period between 1986 and 1999, when the daily depreciation rate volatility was zero in each month, even if the depreciation rate for each month was not known a priori. We did not consider spread as a measure of monetary policy stance because the daily depreciation volatility within a month is not zero after 2001. Nevertheless, we repeat the exercise with spread by replacing it with interest rates. These impulse responses are parallel to Fig. 4, the first column reports the impulses when a one-standard-deviation shock is given to $L$, and the second column reports on the spread with reordered VAR variables. When we compare the first columns of Figs. 4 and 5, a one-standard-deviation shock to $L$ decreases spread in Fig. 5 and increases the interbank rate in Fig. 4. This may suggest that the interbank rate decreases more than the exchange rate depreciates. The estimates on innovations in the interbank rate (Column 2 of Fig. 4) and innovations in spread (Column 2 of Fig. 5) are parallel, including existing puzzles. Innovation in spread increases prices and depreciates local currencies. Thus, using spread for the post-2001 era exhibits both price and exchange rate puzzles. We may therefore claim innovations in $L$ capture the effects of monetary policy changes better than innovations in spread. A set of analyses regarding robustness of the results are presented in the following sub-sections.

\subsection{Evidence from forecast error variance decompositions}

The impulse response functions capture the dynamic effects of various shocks. On the other hand, forecast error variance decomposition (FEVD) analysis captures how shocks contribute to the volatility of various economic aggregates. There are two reasons for looking at the effects of monetary policy shocks using FEVDs. First, FEVDs help to assess whether monetary policy shocks as identified have been an important independent source of impulses for economic performance. Second, the method helps to define the identification strategy, which assumes that changes in monetary policy stance are mostly exogenous shocks to the system.

Table 1 reports the first $6,12,24,30,36,42$ and 48 step-ahead forecast error variances decompositions in income $(y)$, prices $(p)$, exchange rate (exchange), 


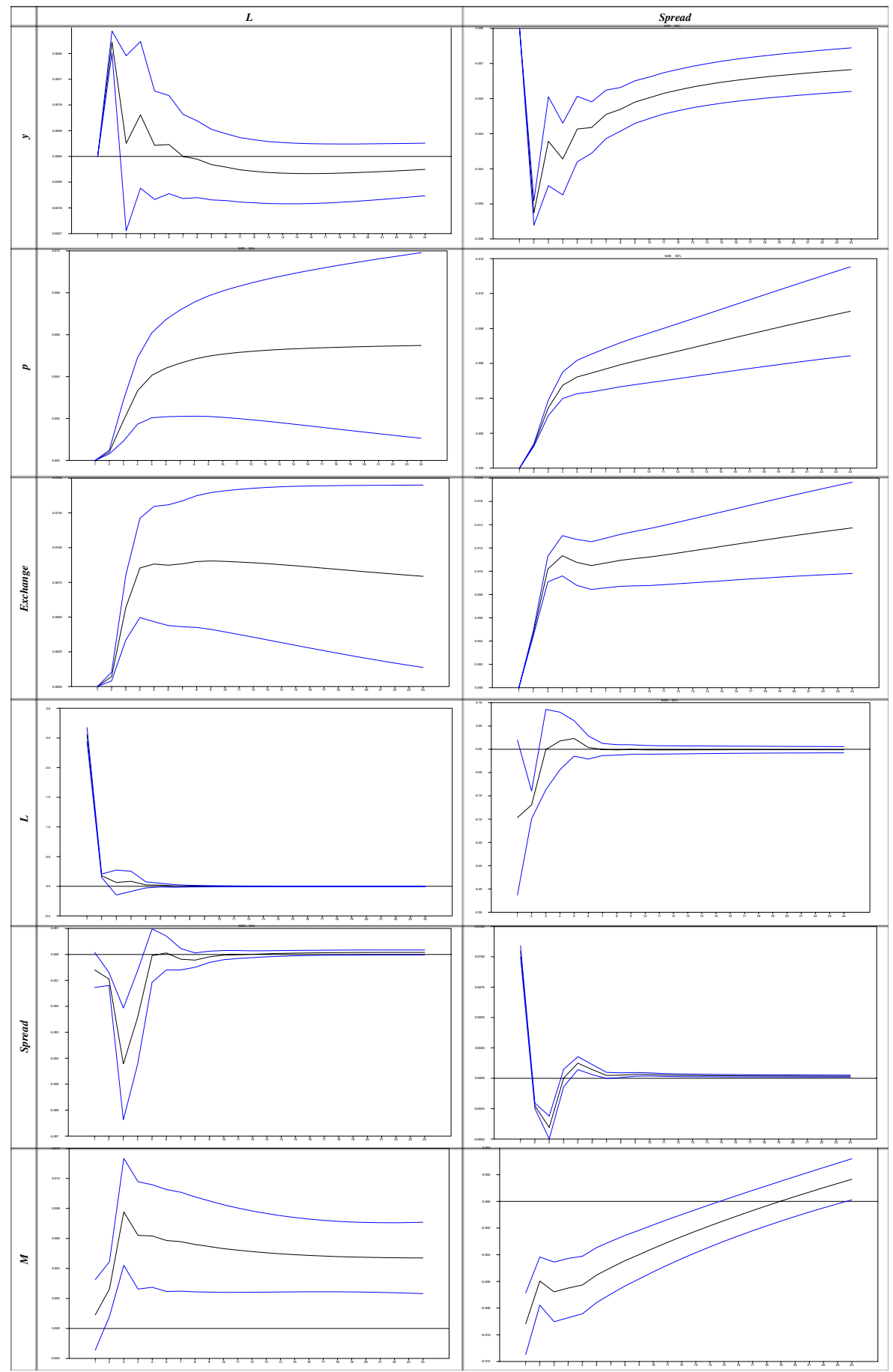

Fig. 5 The effect of monetary policy shocks on economic performance with spread rates 
Table 1 Forecast error variance decomposition: how $L$ explains each variable

\begin{tabular}{ccccccc}
\hline & $y$ & $p$ & exchange & $L$ & interbank & $m$ \\
\hline 6 & 0.15 & 1.38 & 0.01 & $95.65^{\mathrm{a}}$ & 0.15 & 2.66 \\
& $(0.32)$ & $(1.99)$ & $(2.34)$ & $(1.09)$ & $(1.09)$ & $(3.27)$ \\
12 & 0.19 & 1.40 & 0.03 & $95.56^{\mathrm{a}}$ & 0.15 & 2.66 \\
& $(0.27)$ & $(3.05)$ & $(3.35)$ & $(1.17)$ & $(0.94)$ & $(4.15)$ \\
18 & 0.20 & 1.41 & 0.06 & $95.52^{\mathrm{a}}$ & 0.15 & 2.66 \\
& $(0.50)$ & $(3.21)$ & $(3.46)$ & $(1.23)$ & $(0.86)$ & $(4.34)$ \\
24 & 0.20 & 1.41 & 0.08 & $95.49^{\mathrm{a}}$ & 0.15 & 2.66 \\
& $(0.63)$ & $(3.18)$ & $(3.38)$ & $(1.26)$ & $(0.81)$ & $(4.20)$ \\
30 & 0.20 & 1.41 & 0.10 & $95.48^{\mathrm{a}}$ & 0.15 & 2.66 \\
& $(0.69)$ & $(3.11)$ & $(3.27)$ & $(1.28)$ & $(0.78)$ & $(3.87)$ \\
36 & 0.20 & 1.41 & 0.10 & $95.47^{\mathrm{a}}$ & 0.15 & 2.66 \\
& $(0.71)$ & $(3.03)$ & $(3.15)$ & $(1.30)$ & $(0.76)$ & $(3.50)$ \\
42 & 0.20 & 1.41 & 0.11 & $95.46^{\mathrm{a}}$ & 0.15 & 2.66 \\
& $(0.71)$ & $(2.96)$ & $(3.05)$ & $(1.31)$ & $(0.75)$ & $(3.19)$ \\
48 & 0.20 & 1.41 & 0.11 & $95.46^{\mathrm{a}}$ & 0.15 & 2.66 \\
& $(0.69)$ & $(2.89)$ & $(2.95)$ & $(1.31)$ & $(0.74)$ & $(2.97)$ \\
& & & &
\end{tabular}

Standard errors are reported in parentheses under the corresponding coefficients

${ }^{a}$ Indicates significance at the $1 \%$ level

liquidity $(L)$, interbank interest rates (interbank) and money $(m)$ as the percentage of variances, which are attributable to liquidity. Regarding the effect of liquidity on income, it does not have a statistically significant explanatory power, which is parallel to Kim (1999), Kim and Roubini (2000) and Berument (2007). Moreover, there is no statistically significant variation in prices accounted for by liquidity. Importantly, a large variation of liquidity is also explained by itself. This supports the identification strategy, which assumes that innovations in liquidity are exogenous to the system and thus not explained by prices and output. This exogeneity in $L$ innovations can be taken to mean that $L$ innovations are an indicator of monetary policy changes.

\subsection{Evidence from different sub-samples}

In order to assess the validity of our specifications, we repeat the exercise for different sub-samples. First, similar to Berument (2007), we end our sample in 2000:10 and use spread rather than interbank interest rate in the VAR specification for a comparison. The order of the variables is $y$, $p$, exchange, $L$, spread and $m$ in the VAR system. Second, we order the variables such that spread is the policy tool. To be specific, the order of the variables is $y, p$, exchange, spread, $L$ and $m$. A positive innovation in $L$ (loose monetary policy) is associated with higher output, prices and money. On the other hand, the initial decrease in exchange rate is small but statistically significant, and the initial spread increase is also not statistically significant. When spread is the indicator of the policy, the estimates on the second 
column are mostly parallel to Berument (2007). Thus, even if $L$ innovation captures the stance of monetary policy to a degree, evidence suggests that innovations in spread are a superior indicator of the stance of monetary policy than the innovation in $L$ for the pre-2000:10 era.

We also repeat the same exercise for the period from 2001:10 to 2008:04. During this period the exchange rate depreciation was not constant on any day on any given month, so Berument's (2007) identification of monetary policy is not valid. The estimates are robust to our benchmark specification. The estimates with the Berument's (2007) identification suggests that prices increase with positive spread innovations. Even if price increase is not statistically significant, the price puzzle is present. ${ }^{6}$ Therefore, one may argue that even if Berument's (2007) specification does not capture the stance of monetary policy with the innovations in spread for the post2001 era, our identification scheme is valid for both periods (Table 2).

After the Asian crisis in 1997 and the Russian crisis in 1998, the liquidity measure that we had had a high volatility. In order to partially address this, we estimate the model prior to the Asian crisis. To be specific, we estimate the specification until 1997:06. In this particular specification, following Berument (2007), we use M1 + Repo as the money aggregate. ${ }^{7}$ The effect of positive innovation in $L$ is to increase income, prices and money but decrease interbank rate and exchange rate. These results are parallel to our benchmark specification on $L$ as reported in Fig. 4 but for exchange rate. Our estimates for the pre-Asian-crisis period reveal appreciation rather than depreciations. This period needs to be taken causesly because during this period exchange rate is also used as a monetary policy tool (see Berument 2007 for details) and lower exchange rate captures the loose monetary policy that goes with higher $L$.

\subsection{Evidence with the reordered variables}

The impulse response functions are sensitive to the identification scheme. To be specific, in the Cholesky decomposition, the impulse responses are sensitive to the ordering of the variables. In order to assess the robustness of our results, we repeat the exercise with a more flexible identification scheme where we have a nonrecursive short-term identification restriction for the VAR system. With the $L$ innovations the estimates, similar to our benchmark specification, for output increase temporarily, and prices, money, as well as exchange rate, increase permanently. Here interest rate, unlike the benchmark specification, increases, but as in the benchmark specification, this effect is statistically insignificant. As elaborated on in the literature, some use positive interbank rate innovation as an indicator of tight monetary policy. Even if estimates of an output are parallel to benchmark specifications, the estimates reveal that the effect of a positive interest rate

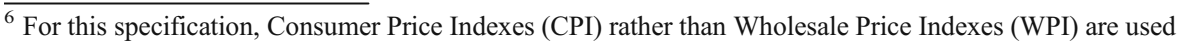
as a measure of prices, where governments use CPI for their budgeting. The CBRT also announced CPIbased inflation targets during the era of explicit and implicit inflation targeting. Moreover, the lag order of the VAR system is 1 rather than 2 for our specification. Even if the impulse responses are similar, confidence bands are narrower with a lag order of 1 .

${ }^{7}$ When we use M1 as the money aggregate the results are mostly the same but the effect of $L$ on $Y$ is statistically significant just for two periods.
} 


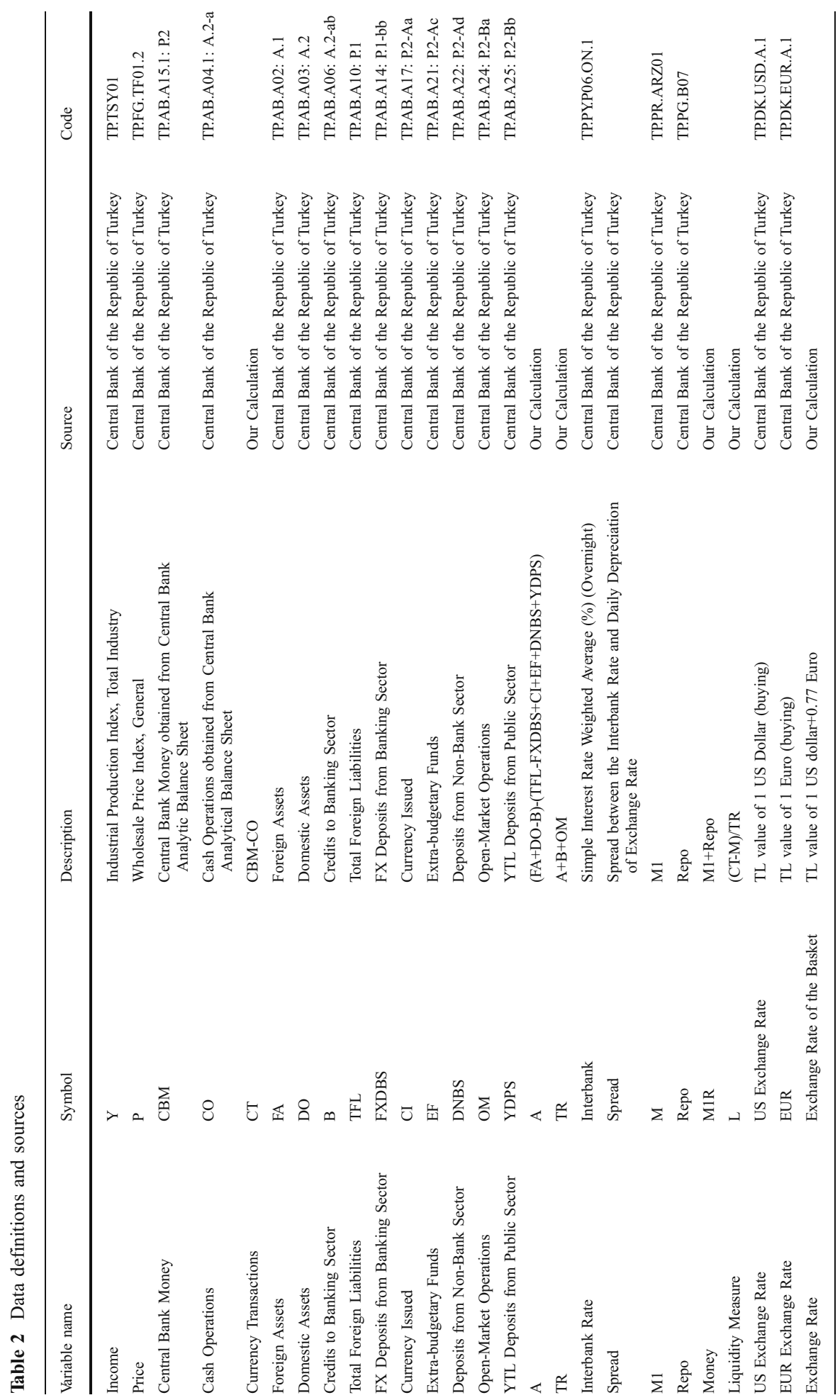


innovation results in the price puzzle (higher prices) and the exchange rate puzzle (with higher exchange rate); moreover, a positive shock on interest rate increases rather than decreases money aggregate. Thus, we safely claim that our identification of the monetary policy tool with $L$ innovation is robust and identifying monetary policy with interest rate innovations is still problematic and reveals that puzzles persist.

\section{Conclusion}

This paper proposes a new liquidity measure for small open economies. Central banks of small open economies use the exchange rate market along with the money markets to stabilize their economies. Therefore, any measure of the stance of monetary policy should consider the developments in foreign exchange markets along with money markets. The contribution of this paper to the literature is to generate a liquidity measure of monetary policy that accounts for central banks' foreign exchange transactions along with their money markets transactions. A new liquidity measure is calculated from the analytical balance sheet of the Central Bank of the Republic of Turkey by considering both the Turkish lira value of foreign exchange transactions and open-market operations. The empirical evidence gathered from Turkey reveals that loose monetary policy (a positive innovation in liquidity) has a transitory effect on output, and a permanent effect on prices, exchange rate and money. The qualitative inferences gathered here are parallel to previous findings of Christiano and Eichenbaum (1992), Sims (1992), Christiano et al. (1999) and Berument (2007).

Acknowledgment Authors would like to thank Rana Nelson and the anonymous referee for their helpful suggestions.

\section{References}

Agénor PR, Montiel PJ (1999) Development macroeconomics, 2nd edn. Princeton University Press, Princeton

Aydogdu H, Yonezer A (2007) The verbal history of the crises. Dipnot (in Turkish), Ankara

Bernanke B (1990) On the predictive power of interest rates and interest rate spreads. New England Economic Review, Federal Reserve Bank of Boston, November-December: 51-68

Bernanke B, Blinder A (1992) Federal funds rate and the channels of monetary transmission. Am Econ Rev 82(4):901-921

Bernanke B, Mihov I (1998) Measuring monetary policy. Q J Econ 113(3):869-902

Berument H (2007) Measuring monetary policy for a small open economy: Turkey. J Macroecon 29:411430

Berument H, Neyapti B (1999) What is the level of independence of Turkish Central Bank? Iktisat, Isletme ve Finans 165:11-17

Berument H, Pasaogullari M (2003) Effects of the real exchange rate on output and inflation: evidence from Turkey. Dev Econ 41:401-435

Berument H, Tasci H (2004) Monetary policy rules in practice: evidence from Turkey. Int J Financ Econ 9:33-38

Bindsell U (2004) Monetary policy implementation theory-past-present. Oxford University Press Inc, New York, pp 44-76 
Carpenter S, Demiralp S (2008) The liquidity effect in the Federal Funds Market: evidence at the monthly frequency. J Money, Credit Bank 40:1-24

CBRT (2007) Monetary and exchange rate policy 2008 (in Turkish)

Christiano LJ (1995) Resolving the liquidity effect: commentary. Federal Reserve Bank of ST Louis Review 77:55-61

Christiano LJ, Eichenbaum M (1992a) Liquidity effects and the monetary transmission mechanism. Am Econ Rev 82:346-352

Christiano LJ, Eichenbaum M (1992b) Identification and the liquidity effect of a monetary policy shock. In: Cukierman A, Hercowitz Z, Leiderman L (eds) Political economy, growth and business cycles. MIT, Cambrige, pp 335-370

Christiano LJ, Eichenbaum M, Evans CL (1999) Monetary policy shocks: what have we learned and to what end? In: Taylor JB, Woodford M (eds) Handbook of macroeconomics, vol 1A. North-Holland, Amsterdam, pp 65-145

Cook D (1999) The liquidity effect and money demand. J Monet Econ 43:377-390

Croushore D, Evans CC (2006) Data revisions and the identification of monetary policy shocks. J Monet Econ 53:1135-1160

Cukierman A (1992) Central bank strategy, credibility and independence. The MIT, Cambridge

Eichenbaum M (1992) Comments on 'Interpreting the macroeconomic time series facts: the effects of monetary policy’ by Christopher Sims. Eur Econ Rev 36:1001-1011

Eichenbaum M, Evans CL (1995) Some empirical evidence on the effect of shock to monetary policy on exchange rates. Q J Econ 110:975-1009

Faust J, Swanson E, Wright JH (2004) Identifying VARs based on the high frequency futures data. J Monet Econ 53:1107-1131

Friedman BM, Kuttner KN (1992) Money, income, prices and interest rates. Am Econ Rev 82:472-492

Geweke JF, Runkle DE (1995) A fine time for monetary policy? Fed Reserve Bank Minneapolis Q Rev 19:18-31

Hanson MS (2006) Varying monetary policy regimes: a vector autoregressive investigation. J Econ Bus 58:407-427

Jang K, Ogaki M (2004) The effects of monetary policy shocks on exchange rates: a structural vector error correction model approach. J Jpn Int Econ 18:99-114

Kamin SB, Rogers JH (2000) Output and the real exchange rate in developing countries: an application to Mexico. J Dev Econ 61:85-109

Kasa K, Popper H (1997) Monetary policy in Japan: a structural VAR analysis. J Jpn Int Econ 11:275-295

Kim S (1999) Do monetary policy shocks matter in the G-7 countries using common identifying assumptions about monetary policy across countries. J Int Econ 48:387-412

Kim S (2001) International transmission of US monetary policy shocks: evidence from VAR's. J Monet Econ 48:339-372

Kim S (2003) Monetary policy, foreign exchange intervention and the exchange rate in a unifying framework. J Int Econ 60:355-386

Kim S, Roubini N (2000) Exchange rate anomalies in industrial countries: a solution with a structural VAR approach. J Monet Econ 45:561-586

Kumcu E, Ötker İ, Saracoglu R (1987) The 1986 monetary programming. The Central Bank of the Republic of Turkey Economic Research Bulletin, January-June, Number 1, 2

Laurent RD (1988) An interest rate-based indicator of monetary policy. Federal Reserve Bank of Chicago Econ Perspect 12:3-14

Mankiw GN, Miron JA (1986) The changing behavior of the term structure of interest rates. Q J Econ 101:211-228

Mosconi R (1998) MALCOLM (Maximum Likelihood CO Integration Analysis of Linear Models. Cafoscarina, Venezia

McCallum BT (2005) Monetary policy and the term structure of interest rates. Federal Reserve Bank of Richmond Economic Quarterly 91:1-21

Normandin M, Phaneuf L (2004) Monetary policy shocks: testing idenfitication conditions under timevarying conditional volatility. J Monet Econ 51:1217-1243

Ozatay F (2006) A catchy interest rate increase is unavoidable (in Turkish) Radikal (June 5, 2006)

Pagan AR, Robertson JC (1995) Resolving the liquidity effect. Fed Reserv Bank St Louis Rev $77: 33-54$

Rotemberg JJ, Driscoll JC, Poterba JM (1995) Money, output and prices: evidence from a new monetary aggregate. J Bus Econ Stat 13:67-83

Rudebusch GD (1998) Do measures of monetary policy in a VAR make sense. Int Econ Rev 39:907-931 
Sahin A (2009) The relationship between trade openness ratio and aggregate output: an application on Turkey (1989-2008). Ekev Academic Review 13:413-432

Scholl A, Uhlig H (2008) New evidence on the puzzles: results from agnostic identification on monetary policy and exchange rates. $\mathrm{J}$ Int Econ 76:1-13

Shioji E (2000) Identifying monetary policy shocks in Japan. J Jpn Int Econ 14:22-42

Silva CV (2008) Monetary policy and the US housing market: a VAR analysis imposing sign restrictions. J Macroecon 30:977-990

Sims CA (1972) Money, income and causality. Am Econ Rev 62:540-552

Sims CA (1992) Interpreting the macroeconomic time series facts. Eur Econ Rev 36:975-1011

Sims CA, Zha T (1999) Error bands for impulse responses. Econometrica 67:1113-1155

Stock JH, Watson M (1989) Interpreting the evidence on money-income causality. J Econometrics 40:161-181

Strongin S (1995) The identification of monetary policy distrubances: explaining the liquidity puzzle. J Monet Econ 35:463-498

Thornton DL (2001) The Federal Reserve's operating procedure, nonborrowed reserves, borrowed reserves and the liquidity effect. J Bank Finance 25:1717-1739

Uhlig H (2005) What are the effects of monetary policy on output? Results from an agnostic identification procedure. J Monet Econ 52:381-419 